\title{
Centroglossa tripollinica (Barb. Rodr.) Barb. Rodr. (Orchidaceae: Oncidiinae): lectotypification and rediscovery in the State of Paraná, Brazil ${ }^{1}$
}

\author{
Carla Adriane Royer ${ }^{2,5}$, Antonio Luiz Vieira Toscano de Brito ${ }^{3}$ and Eric de Camargo Smidt ${ }^{4}$ \\ Received: 25.11.2016; accepted: 31.01.2017
}

\begin{abstract}
Centroglossa tripollinica (Barb. Rodr.) Barb. Rodr. (Orchidaceae: Oncidiinae): lectotypification and rediscovery in the State of Paraná, Brazil). The genus Centroglossa consists of six species, all endemic to the Atlantic Forest in southern and southeastern Brazil. It was known to occur in the State of Paraná based on three specimens of C. tripollinica collected by the Swedish botanist Per Karl Hjalmar Dusén at the beginning of last century. During recent fieldwork in Brazil, this species was rediscovered in Paraná. The aim of this article is to confirm the presence of C. tripollinica in the State of Paraná, provide a detailed description and illustrations of this species, and discuss its conservation status. A lectotype is designated for C. tripollinica.

Keywords: Atlantic Forest, Biodiversity, Flora of Paraná, IUCN
\end{abstract}

RESUMO - (Centroglossa tripollinica (Barb. Rodr.) Barb. Rodr. (Orchidaceae: Oncidiinae): lectotipificação e redescoberta no Estado do Paraná, Brasil). O gênero Centroglossa consiste de seis espécies endêmicas da Mata Atlântica do sul e sudeste brasileiros. No Estado do Paraná, o gênero encontrava-se registrado por três coleções pertencentes à $C$. tripollinica, todas realizadas pelo botânico suéco Per Karl Hjalmar Dusén. Durante a realização de recentes trabalhos de campo no Paraná, a referida espécie foi redescoberta no Estado. O objetivo deste artigo é confirmar a presença de C. tripollinica no Paraná, detalhando-a por meio de uma descrição e ilustração, além de discutir o seu presente estado de conservação. Um lectótipo é selecionado para C. tripollinica.

Palavras-chave: Biodiversidade, Flora do Paraná, IUCN, Mata Atlântica

\section{Introduction}

The genus Centroglossa Barb. Rodr. consists of six species of erect to pendulous, small epiphytic orchids restricted to the Atlantic Forest in southern and southeastern Brazil. It is a member of the Ornithocephalus clade of subtribe Oncidiinae and apparently related to the genus Zygostates Lindl., with which it shares similar vegetative and floral morphology (Toscano de Brito 2001, Chase \& Toscano de Brito 2009). However, it is readily distinguished from Zygostates by its distinctive spurred lip.

Barbosa Rodrigues (1877) described Centroglossa based on two species, C. macroceras Barb. Rodr. and
C. tripollinica (Barb. Rodr.) Barb. Rodr. The latter species was originally described as Ornithocephalus tripollinicus Barb. Rodr. and was selected as the lectotype of the genus (Toscano de Brito 2001).

In this work we describe and illustrate Centroglossa tripollinica, the only species so far known to occur in Paraná. We also provide nomenclatural notes and conservation status of this species in the state.

\section{Material e methods}

This study was based on review of literature, examination of living fertile plants and specimens

1. Parte da Tese de Doutorado do primeiro Autor

2. Universidade Estadual Paulista "Júlio de Mesquita Filho", Instituto de Biociências, Departamento de Botânica, Av. 24-A, 1515, 13506-900 Rio Claro, São Paulo, Brasil

3. Marie Selby Botanical Gardens, 811 South Palm Avenue, Sarasota, FL. 34236, U.S.A. Associate, Oakes Ames Orchid Herbarium, Harvard University Herbarium, U.S.A.

4. Universidade Federal do Paraná, Centro Politécnico, Setor de Ciências Biológicas, Departamento de Botânica, Av. Cel. Francisco H. dos Santos, s.n., Jardim das Américas 80530-900 Curitiba, PR, Brasil

5. Corresponding author: carladriane@gmail.com 
deposited in the herbaria BHCB, BR, HB, P, RB, S, SP and UPCB (acronyms according to Thiers 2016), and supplemented with material collected on fieldwork. Morphological descriptions followed the terminology used by Toscano de Brito (1994, 2001) and Stern (2004). Synonyms accepted in this study followed Toscano de Brito (2001).

The conservation status of the taxon was inferred by following IUCN's recommendations (2010), which considered the number of locations, the area of occupancy, and the extent and quality of the habitat.

The description of the species's habitat was based on Maack (1968) and Veloso et al. (1991).

\section{Results and Discussion}

Centroglossa tripollinica is the only representative of this genus in Paraná. A new record (C.A. Royer et al. 134) confirms the unpublished information provided by one of us (Toscano de Brito 1994), who previously cited the presence of the genus Centroglossa in the State. This citation was based on a specimen of $C$. tripollinica collected by the Swedish botanist and explorer Per Karl Hjalmar Dusén (1855-1926), which is deposited in the herbarium of the Swedish Museum of Natural History (S).

Centroglossa tripollinica (Barb. Rodr.) Barb. Rodr. Gen. Sp. Orchid. 2: 235. 1882.= Ornithocephalus tripollinicus Barb. Rodr., Gen. Sp. Orchid. 1: 136. 1877. TYPE: BRAZIL: Minas Gerais: Poços de Caldas, in wet forests, flowered in April, J. Barbosa Rodrigues s.n. (Holotype: Lost; lectotype here designated: illustration tab. 312, fig. A, vol. 6, in Iconogr. Orchid. Brésil at the Library of Rio de Janeiro Botanical Garden, cited as tab. 461 (then unpublished) in Barb. Rodr. loc. cit; copied and reproduced in black and white in Cogn., Fl. Bras. (Mart.) 3(5), tab.46, fig.1, 1.1904.; reproduced in color in Sprunger et al., 1996, vol. 1: 440, fig. A).

Figures 1-3

Plant sympodial, 32-48 mm tall. Roots caespitose, hairy. Pseudobulbs 3.6-7.5 × 1.4-2.2 mm, unifoliate, oblong, partially covered by the sheaths of the lateral leaves. Lateral leaves 14.8-32.6 × 1.9-3.6 mm, distichous, bifacial, elliptical, fleshy, abaxially keeled, apex acute, articulated with a V-shaped sheath. Apical leaf similar to the lateral ones, sessile and articulated with the pseudobulb. Inflorescence 16-21 mm long, emerging from the base of the pseudobulb, laxly covered by lanceolate bracts. Flowers resupinate or non-resupinate. Sepals 2.2-2.4 × 1.5-2 mm, white, slightly greenish at apex, incurved, obovate, concave, abaxially keeled, margins obscurely crenulate, apex obtuse. Petals 1.9-2.8 × 1.6-1.9 mm, white, incurved, obovate, concave, abaxially keeled, margins obscurely crenulate, apex obtuse. Lip 3.2-4.5 × 1.8-2.4 mm, white, deflexed, distinctly infundibuliform, markedly spurred, obscurely lobed at apex, glandular within, with a fleshy, white callus embedded on the disc near the attachment to column, margins entire, apex obtuse. Column short, straight or slightly curved, with a pair of conspicuous, lateral, arm-like, white appendages at base; stigmatic cavity rounded, occupying a large portion of the abaxial surface of the column; rostellum spreading or projected forwards; anther ca. $1 \mathrm{~mm}$ long, acute; pollinia four, arranged in two superposed, subequal pairs, stipe elongate, linear-spatulate, viscidium, dorsal, elliptic. Capsule ca. $10.8 \times 6.5 \mathrm{~mm}$, triangular in cross-section with wavy wings at angles.

Material examined: BRAZIL. Paraná: Without Locality, 1908-1916, P.K.H. Dusén s.n. (S1644828). Quatro Barras, Morro Mãe Catira, Rodovia da Graciosa, 13-V-2016, C.A. Royer et al. 134 (UPCB, spirit).

Additional material examined: BRAZIL. WiTHOUT LoCALITY, obtained from a private collector, fl. cult. in Curitiba by M. Klingelfus s.n., 22-VI-2015, $A$. Toscano de Brito 3408 (UPCB, spirit); 1-VI-2016, C.A. Royer 135 (UPCB, spirit); 1-VI-2016. EsPíRITO Santo: Castelo, s.d., A.C. Brade 30 (HB). Minas Gerais: Bom Jardim de Minas, 12-V-1961, J.E. Saléh 60 (HB). Caldas, near Fazenda Capivary, 15-V-1874, C.W.H. Mosén 1708 (S, spirit). Caldas, s.d., A.F. Regnell III-1171 (S). Caldas, Pedra Branca, 18-VIII1857, A.F. Regnell III-1170 (S; SP; P). Conceição do Mato Dentro, Parque Natural Municipal do Ribeirão do Campo, 8-VIII-2002, R.C. Mota et al. 2516 (BHCB). Rio De JANEiro: Itatiaia, lote 88, $900 \mathrm{~m}$, II-1942, A.C. Brade 17336 (RB). Serra dos Orgãos, ?-1887, J.T. de Moura 49 (BR).

Centroglossa tripollinica was first described in the genus Ornithocephalus Hook. based on a specimen from Poços de Caldas, in the State of Minas Gerais, southeastern Brazil. The type specimen of Ornithocephalus tripollinicus was lost (Cribb \& Toscano de Brito, 1996), and the only extant original material is the illustration which appeared in Barbosa Rodrigues's Iconographie des orchidées du Brésil, which is now deposited in the library of Rio de Janeiro Botanical Garden. This illustration was copied and 

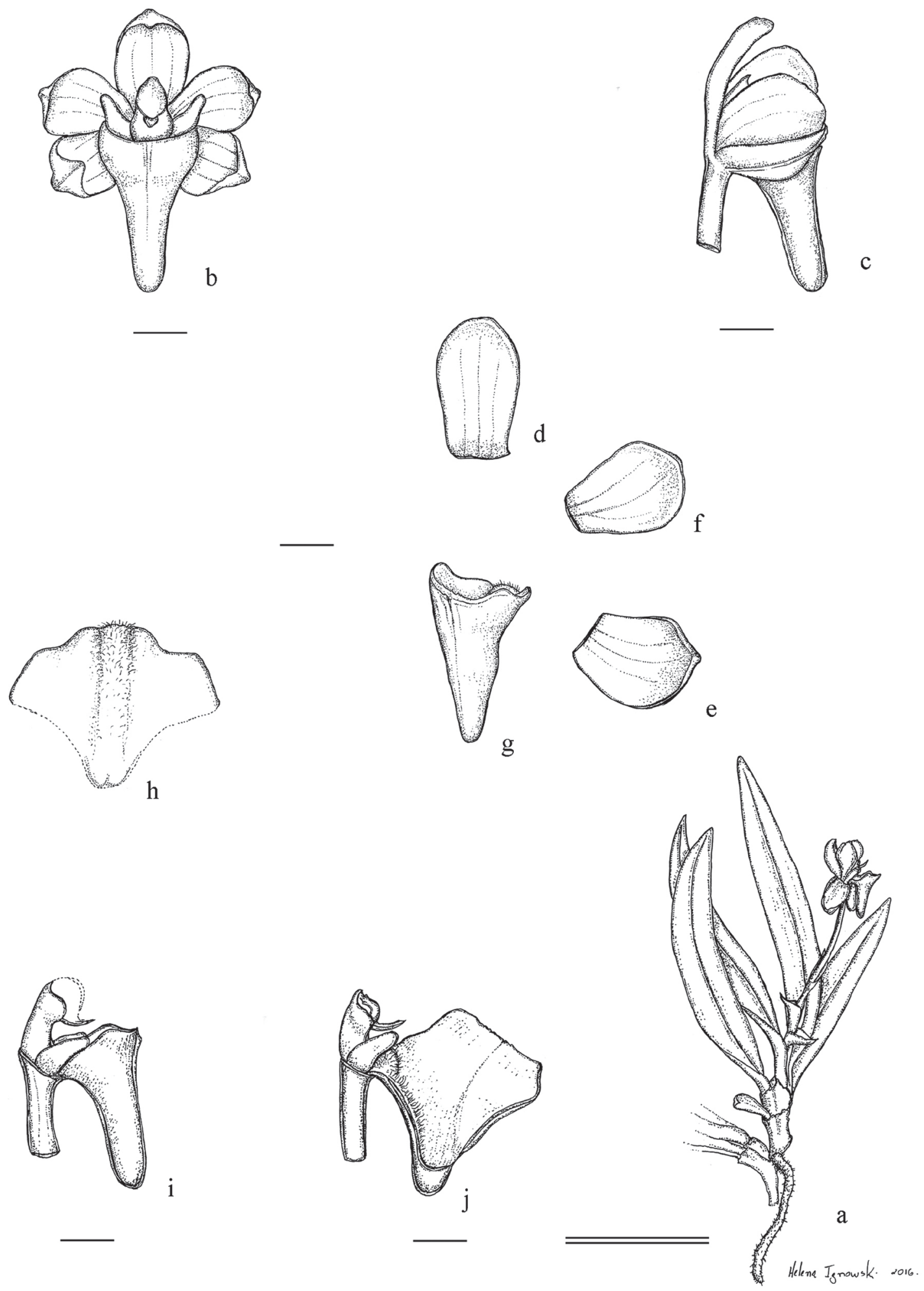

Figure 1. Centroglossa tripollinica (Barb. Rodr.) Barb. Rodr. a. Habit. b. Flower, frontal view. c. Flower, lateral view. d. Dorsal sepal. e. Lateral sepal. f. Petal. g. Lip, lateral view. h. Lip, longitudinal section. i. Ovary, column and lip, lateral view. j. Ovary, column and lip in lateral view, anther removed and lip laterally sectioned (C.A. Royer 134). Double-line scale $=1 \mathrm{~cm}$. Single-line scale $=1 \mathrm{~mm}$. 


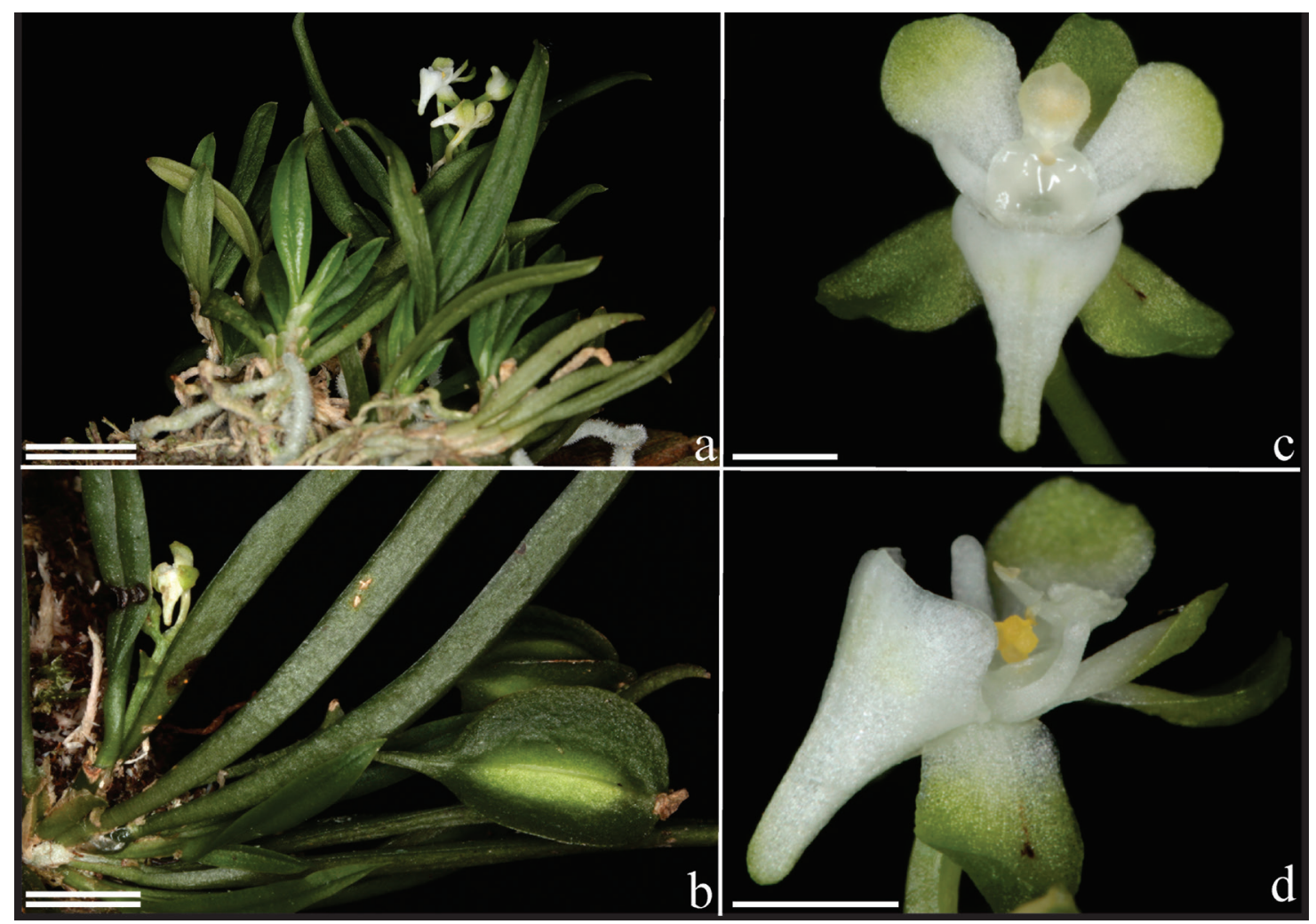

Figure 2. Centroglossa tripollinica (Barb. Rodr.) Barb. Rodr. a. Habit (C.A. Royer et al. 135). b. Habit showing immature fruit (C.A. Royer 134). c. Flower, frontal view (C.A. Royer et al. 135). d. Flower; lateral view (C.A. Royer et al. 135). Double-line scale $=5$ mm. Single-line scale $=1 \mathrm{~mm}$.

reproduced in black and white in Cogniaux (1904), and later reproduced in color in Sprunger et al. (1996). It is here selected as the lectotype.

Centroglossa tripollinica is apparently well distributed in the Atlantic Forest in southeastern Brazil. However, to our current knowledge no specimen has been collected and deposited in a herbarium in over 40 years. It has been reported for the States of Espírito Santo, Minas Gerais, Rio de Janeiro and Paraná (Kraenzlin 1911, Pabst \& Dungs 1977, BFG 2015). Hoehne (1953), Pabst \& Dungs (1977) and BFG (2015) cited this species for the State of São Paulo, but so far we have been unable to confirm this information. In the state of Paraná, Centroglossa tripollinica seems to be uncommon, so far only found in the Floresta Ombrófila Densa in Serra do Mar, a region that houses part of the largest remnant of Atlantic Forest in Brazil (PROBIO 2007) and presents great richness and diversity of Ornithocephalus clade (Royer et al. 2014, Estevinho et al. 2016). Apart from the specimen collected in the municipality of Quatro Barras (C.A. Royer et al. 134), the authors are aware of three other collections by Dusén. One of them, Dusén s.n., which is deposited at S (figure 3), was studied by one of us (ALVTB). It has no precise locality noted and was collected between 1908 and 1916. The other two specimens, Dusén 10098 and Dusén 10287, were cited by Kraenzlin (1911), but unfortunately we have been unable to locate these collections. It is possible that they were destroyed during the bombing of the Berlin herbarium (B) as Kraenzlin's herbarium is known to have been acquired by B in 1907 (Stafleu \& Cowan 1979). Two additional collections without provenance, A. Toscano de Brito 3408 (UPCB) and C.A. Royer 135 (UPCB), are based on the same individual. They flowered in cultivation in Curitiba and might have been collected in Paraná. One of them, C.A. Royer 135 , is illustrated in figure $2 \mathrm{a}, \mathrm{c}-\mathrm{d}$.

Based on the IUCN criteria (2010), C. tripollinica was previously considered "Possibly Extinct" locally, as over 100 years has passed since it was last collected. With present evidence, the species should now be placed in the category "Critically Endangered" (VU D2 CR) in Paraná State, because the area of distribution is very limited, and there is a natural and/ or anthropogenic threat. 


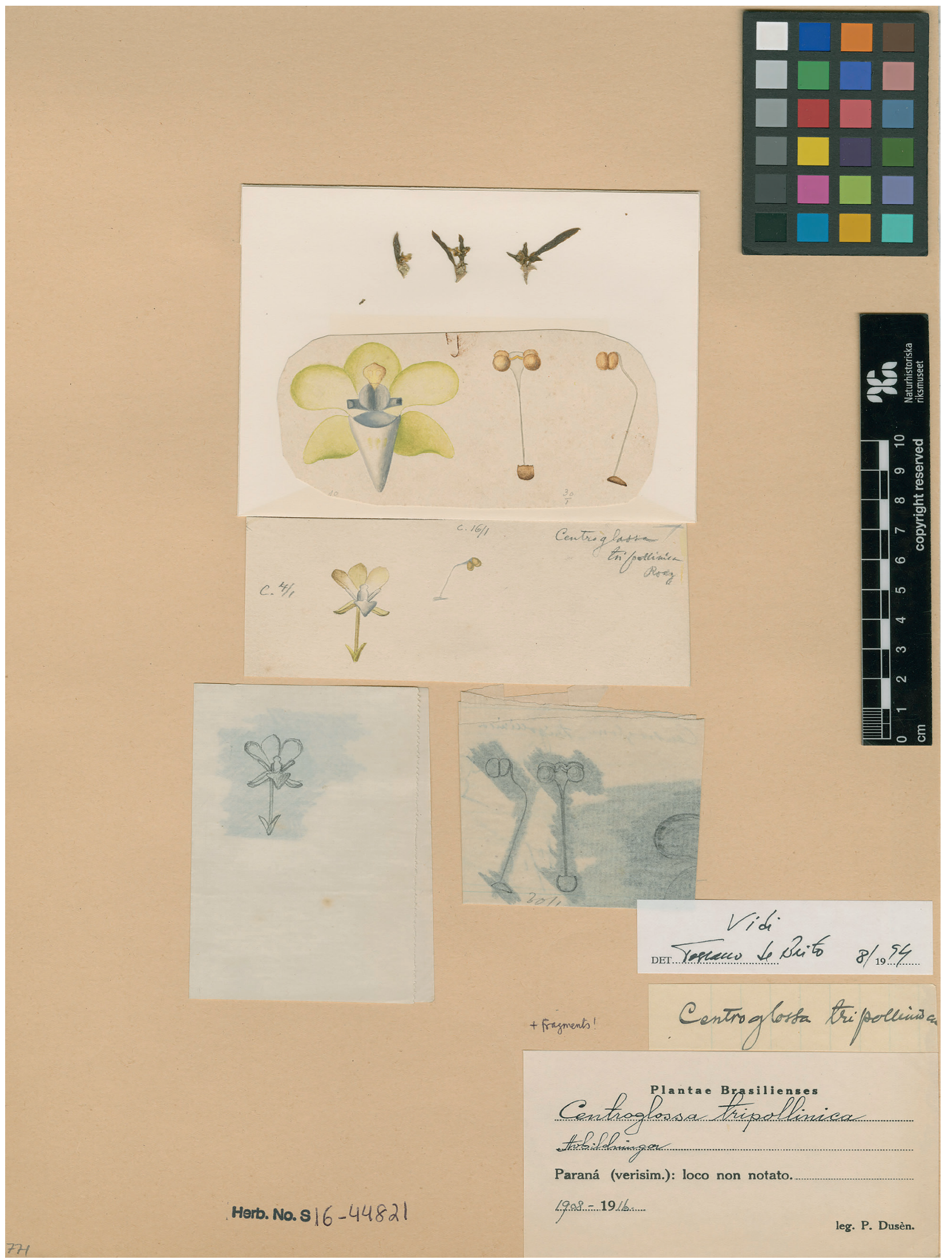

Figure 3. Dusén's collection deposited at S. It has no precise locality noted and it was collected between 1908 and 1916. By permission of the Keeper, Herbarium of the Swedish Museum of Natural History. 


\section{Acknowledgements}

The authors are grateful to Wade Collier for helping assemble the images and editing the text, Helena Ignowski for preparing the black and white illustrations, and the Marie Selby Botanical Gardens for providing funds for the artwork. We thank the following herbaria for the privilege of studying their collections: BHCB, BR, HB, P, RB, S, SP and UPCB. We also thank the Keeper of the Herbarium of the Swedish Museum of Natural History (S) for permission to reproduce the image which appears in figure 3. CAR and ALVTB acknowledge Coordenação de Aperfeiçoamento de Pessoal de Nível Superior (CAPES) for a doctoral grant and grant Programa Pesquisador Visitante Especial (PVE), 88881.065009/2014-0, respectively. ECS thanks Conselho Nacional de Desenvolvimento Científico e Tecnológico (CNPq) for Bolsa de Produtividade em Pesquisa CNPq-Nível 2 (processo 311001/2014-9) and for grant MCTI/CNPq 14/2013 - Universal (processo 485396/2013-0).

\section{Literature cited}

Barbosa Rodrigues, J. 1877 . Genera et Species Orchidearum Novarum quas Collecit, Descripsit et Iconibus Illustravit. 1 ed. Typographia Nacional, Rio de Janeiro.

BFG. 2015. Growing knowledge: an overview of Seed Plant diversity in Brazil. Rodriguésia 66: 1085-1113.

Chase, M.W. \& Toscano de Brito, A.L.V. 2009. Zygostates. In: A.M. Pridgeon, P.J. Cribb, M.W. Chase \& F. Rasmussen (orgs.). Genera Orchidacearum: Epidendroideae (Part 2), v. 5, 1 ed. Oxford University Press Inc, New York., pp. 391-394.

Cogniaux, A. 1904. Centroglossa Barb. Rodr. In: C.F. P. von Martius, A.W. Eichler \& I. Urban (eds.). Flora Brasileinsis. v. 3, Part 6. R. Oldenbourg, Monachii et Lipsiae, pp. 188-192.

Cribb, P.J. \& Toscano de Brito, A.L.V. 1996. Introduction and History. In: S. Sprunger, P.J. Cribb \& A.L.V. Toscano de Brito (eds.). João Barbosa Rodrigues: Iconographie des orchidées du Brésil. v. 1. The Illustrations. Friedrich Reinhardt, Basle, pp. 23-30.

Estevinho, T.F., Toscano de Brito, A.L.V. \& Smidt, E.C. 2016. O gênero Ornithocephalus Hook. (Orchidaceae: Oncidiinae) nos estados do Paraná e Santa Catarina. Acta Biológica Paranaense 45: 1-9.
Hoehne, F.C. 1953. Centroglossa. In: F.C. Hoehne (ed.). Flora Brasílica, Orchidaceas. v. 12, n. 7. Companhia Brasileira de Impressão e Propaganda, São Paulo, pp. 375-381.

IUCN - Standards and Petitions Subcommittee. 2010. Guidelines for Using the IUCN Red List Categories and Criteria. Version 8.1. Prepared by the Standards and Petitions Subcommittee in March 2010. Available in http://www.iucnredlist.org/documents/ RedListGuidelines.pdf/ (access in 05-VI-2016).

Kraenzlin, F. 1911. Beitrage zur Orchideenflora Südamerikas. Kongl. Svenska Vetenskapsakademiens Handlingar 46: 1-115.

Maack, R. 1968. As zonas das paisagens naturais. In: R. Maack (ed.). Geografia física do Paraná. BADEP, Curitiba.

Pabst, G.F.J. \& Dungs, F. 1977. Orchidaceae Brasilienses. v. 2. Brucke-Verlag Kurt Schmersow, Hildesheim.

PROBIO - Projeto de Conservação e Utilização Sustentável da Diversidade Biológica Brasileira. 2007. Levantamento da Cobertura Vegetal Nativa do Bioma Mata Atlântica. Instituto de Estudos Socioambientais do Sul da Bahia (IESB), Rio de Janeiro.

Royer, C.A., Toscano de Brito, A.L.V. \& Smidt, E.C. 2014. O gênero Phymatidium Lindl. (Orchidaceae: Oncidiinae) no estado do Paraná. Rodriguésia 65: 251-260.

Sprunger, S., Cribb, P. \& Toscano de Brito A.L.V. (eds.). 1996. João Barbosa Rodrigues: Iconographie des orchidées du Brésil. v. 1. The Illustrations. Friedrich Reinhardt, Basle.

Stafleu, F.A. \& Cowan, R.S. 1979. Taxonomic Literature. A selective guide to botanical publications and collections with dates, commentaries and types. 2 ed. v. 2. H-Le. Bohn, Scheltema \& Holkema, Utrecht.

Stern, W.T. 2004. Botanical Latin. Timber Press, Portland.

Thiers, B. 2016. Index Herbariorum. Part I: The herbaria of the world. New York Botanical Garden. Available in http://sweetgum.nybg.org/ih/ (access in 05-VI-2016).

Toscano de Brito, A.L.V. 1994. Systematic studies in the subtribe Ornithocephalinae (Orchidaceae). Tese de Doutorado. Universidade de Reading e Royal Botanic Gardens, Londres.

Toscano de Brito, A.L.V. 2001. Systematic review of the Ornithocephalus group (Oncidiinae: Orchidaceae) with comments on Hofmeisterella. Lindleyana 16: 157-217.

Veloso, H.P., Rangel Filho, A.L.R. \& Lima, J.C.A. 1991. Classificação da vegetação brasileira adaptada a um sistema universal. IBGE/Projeto Radambrasil, Rio de Janeiro. 